\title{
SPISY POWSZECHNE W POLSCE W LATACH 1921-2011 - OKREŚLANIE CZY KREOWANIE STRUKTURY NARODOWOŚCIOWEJ?
}

\begin{abstract}
Zarys treści: $\mathrm{W}$ artykule podjęto próbę odpowiedzi na pytania, na ile metody przeprowadzenia spisów powszechnych, sformułowania tzw. pytań etnicznych oraz bieżące uwarunkowania polityczne i społeczne mogą kształtować ich wyniki w odniesieniu do struktury narodowościowej. Omówiono spisy ludności przeprowadzone w Polsce w ciągu ostatnich 90 lat, zwracając szczególną uwagę na czynniki, które mogły spowodować wypaczenie ich rezultatów. Skupiono się nie tyle na kolejnym przedstawieniu - powszechnie znanych - wyników w ujęciu ilościowym i przestrzennym, ale na „mechanizmie" przeprowadzenia spisu w kontekście ówczesnych realiów politycznych i społecznych.
\end{abstract}

Słowa kluczowe: struktura narodowościowa Polski, spis powszechny, mniejszości narodowe.

\section{Wprowadzenie}

Rzetelne określenie struktury narodowościowej Polski w trakcie ostatnich kilkudziesięciu lat jest bardzo trudne, głównie $\mathrm{z}$ powodu dynamicznych zmian politycznych, społecznych, terytorialnych i demograficznych, niesprzyjających deklaracjom narodowościowym uwarunkowań politycznych oraz zróżnicowanej rzetelności - lub wręcz braku - oficjalnej statystyki narodowościowej (Eberhardt 1996, 2006, 2008; Chałupczak, Browarek 1998; Sobczyński 2000, Gawryszewski 2005). Różnie sformułowane pytania dotyczące struktury narodowościowej uwzględniało pięć spisów powszechnych (w roku 1921, 1931, 1946, 2002, 2011), jednak przeprowadzenie ich zróżnicowanymi metodami w diametralnie odmiennych uwarunkowaniach politycznych i społecznych mogło w istotniejszy sposób wpłynąć na rezultaty ,etniczne”, niż zachodzące procesy demograficzne i ewolucja poczucia przynależności narodowej obywateli. Ponadto bardzo nieliczne spisy ludności w Polsce spełniały wszystkie teoretyczne kryteria ich przeprowadzenia. Według demografa Z. Holzera (1989) spis powszechny, jeżeli ma ustalić 
strukturę ludności według wybranych cech, musi zostać przeprowadzony w ściśle określonym czasie i terytorium za pomocą indywidualnego pozyskiwania informacji o całej badanej populacji. Natomiast geograf ludności A. Gawryszewski (2005) zwraca uwagę na cztery podstawowe kryteria spisów ludności: powszechność (obejmuje wszystkich mieszkańców), jednoczesność (przeprowadzany jest na całym terytorium według stanu w określonym dniu), imienność (każda osoba spisywana jest z imienia i nazwiska) i bezpośredniość (odpowiedzi uzyskuje się od osoby spisywanej).

\section{Spis w 1921 roku}

Określenie liczebności i rozmieszczenia mniejszości narodowych w Polsce w okresie międzywojennym jest bardzo trudne, głównie z powodu niestabilnej sytuacji wewnętrznej młodego państwa, ruchów migracyjnych, polityki rządu dotyczącej spisów powszechnych i wątpliwej ich wiarygodności w kwestii mniejszości narodowych. Podczas spisów ludności dochodziło do bezpośredniego fałszowania wyników (zwłaszcza w województwach południowo-wschodniej Polski), tendencyjnego zadawania pytań, stosowania nierzetelnych metod zbierania i opracowywania danych oraz bojkotu spisu przez niektóre grupy narodowościowe nieuznające polską suwerenność (Tomaszewski 1985; Eberhardt 1996; Gawryszewski 2005).

Pierwszy po wojnie spis ludności przeprowadzono 30 września 1921 roku. Jego wyniki - nie tylko w kwestiach narodowościowych - nie przedstawiają ówczesnej struktury ludności, głównie ze względu na ich niekompletność. W momencie przeprowadzania spisu terytorium Polski nie było definitywnie ustalone. Spis nie objął Wileńszczyzny i Górnego Śląska - regionów silnie zróżnicowanych pod względem etnicznym, zamieszkanych przez ponad $1,5 \mathrm{mln}$ osób, ponadto został zbojkotowany przez dużą część najliczniejszej ówczesnej mniejszości narodowej, czyli Ukraińców, spośród których wielu odmawiało uznania nowych polskich władz. W jego trakcie trwały jeszcze masowe repatriacje ludności z Rosji oraz powojenne wewnętrzne ruchy migracyjne. Po zakończeniu spisu do Polski powróciło ok. 0,5 mln osób, nie tylko narodowości polskiej. Z powodu uwarunkowań społeczno-politycznych (m.in. dopiero zakończonej wojny z sowiecką Rosją, konflikcie z Ukraińcami, wytyczaniu granic, wprowadzaniu polskiej administracji) był bardzo nieufnie przyjęty we wschodnich regionach Rzeczpospolitej. Dlatego wyniki spisu z 1921 roku są niewystarczające dla określenia struktury narodowościowej ówczesnej Polski, mimo że formularz spisowy zawierał pytania dotyczące narodowości, języka ojczystego (tych wyników nie opublikowano) oraz wyznania (Gawryszewski 2005). Nie objął całego terytorium Polski ani wszystkich mieszkańców (zaledwie 25,7 mln, kolejny spis 10 lat później już prawie $32 \mathrm{mln}$ ). Z pewnością zaniżył liczebność mniejszości narodowych, zwłaszcza ukraińskiej (rusińskiej), niemieckiej i litew- 
skiej. Ponadto część ludności utożsamiała pytanie o narodowość z obywatelstwem odrodzonego państwa polskiego, co dodatkowo wpłynęło na zawyżenie liczby Polaków (tab. 1).

\section{Tabela 1}

Struktura narodowościowa Polski na podstawie wyników spisu z 1921 roku

\begin{tabular}{|l|r|c|}
\hline \multirow{2}{*}{ Narodowość } & \multicolumn{2}{|c|}{ Liczebność } \\
\cline { 2 - 3 } & (tys.) & (\%) \\
\hline Polacy & 17789 & 69,20 \\
\hline Rusini & 3898 & 15,20 \\
\hline Żydzi & 2050 & 8,00 \\
\hline Białorusini & 1036 & 4,00 \\
\hline Niemcy & 769 & 3,00 \\
\hline Rosjanie & 49 & 0,20 \\
\hline Czesi & 31 & 0,12 \\
\hline Litwini & 24 & 0,09 \\
\hline Inna & 49 & 0,20 \\
\hline
\end{tabular}

Źródło: opracowanie własne na podstawie A. Gawryszewski (2005, s. 246).

\section{Spis z 1931 roku}

Dla zobrazowania liczebności i rozmieszczenia mniejszości narodowych w okresie międzywojennym stosuje się z reguły wyniki kolejnego spisu z 1931 roku. Jednak ich wiarygodność, zwłaszcza $\mathrm{w}$ odniesieniu do zamieszkanej przez Ukraińców, Białorusinów i Litwinów wschodniej Polski, była podważana już w okresie międzywojennym, a w pierwszych latach powojennych były prezes Głównego Urzędu Statystycznego z lat 30. XX wieku Edward Szturm de Sztrem $^{1}$, podał informacje o licznych manipulacjach i fałszerstwach zarówno w trakcie spisu, jak i na etapie obróbki danych. Najpowszechniejszym fałszerstwem na szczeblu starostwa powiatowego było skreślanie przez urzędników w rubryce język ojczysty słowa „białoruski” lub „ukraiński” i wpisywanie języka polskiego. Skala manipulacji była tak duża, że władze GUS domagały się ponownego przeprowadzenia spisu w województwach wschodniej Polski, na co nie wyraziło zgody MSW. Wymowny jest również brak publikacji wyników

\footnotetext{
${ }^{1}$ W latach 1929-1939 prezes GUS, po wojnie (1946-1950) rektor Akademii Nauk Politycznych, następnie w latach 50. XX wieku profesor Szkoły Głównej Planowania i Statystyki.
} 
spisu w odniesieniu do gmin, co łatwo mogło wykazać fałszerstwa i manipulacje (Tomaszewski 1985; Chałupczak, Browarek 1998; Gawryszewski 2005).

W trakcie spisu w 1921 roku pytanie o narodowość niekiedy błędnie utożsamiano z obywatelstwem. Z tego powodu w kolejnym spisie w 1931 roku zlikwidowano pytanie o narodowość, natomiast strukturę etniczną postanowiono ustalić na podstawie odpowiedzi na pytanie o język ojczysty, w przekonaniu że zmniejszy to możliwość nieporozumień. W instrukcji spisowej wyjaśniono, że jako język ojczysty należy wpisać ,język, który dana osoba uważa za najbliższy sobie”. W formularzu spisowym wymieniono wyłącznie język ,polski, ukraiński, ruski, żydowski, białoruski, niemiecki, litewski, rosyjski, czeski lub jaki inny". Tego typu ograniczenie skutecznie utrudniało wykazanie w spisie m.in. mniejszości słowackiej, ormiańskiej czy tatarskiej. Z kolei umieszczenie w formularzu spisowym zarówno języka ukraińskiego, jak i ruskiego było spowodowane identyfikowaniem przez część Ukraińców i Łemków własnego języka jako ruskiego, a nie ukraińskiego. Ponadto osobne uwzględnienie w oficjalnych wynikach spisu ludności ukraińskiej i rusińskiej było korzystne z punktu widzenia ówczesnej polityki polskich władz - „rozbijało” społeczność ukraińską, zmniejszało jej liczebność, zwiększało wieloetniczny charakter niektórych regionów Polski, pozwalało liczebnie dominować ludności deklarującej język polski ${ }^{2}$. Natomiast w formularzu dla województwa poleskiego wyraz „ruski” został pominięty, ponieważ większość miejscowej ludności prawosławnej używała go do określenia zarówno narodowości ukraińskiej, białoruskiej, jak i rosyjskiej i zastąpiony, wyłącznie w tym województwie, określeniem ,język tutejszy”.

Powszechnie uważa się, że zastosowane w 1931 roku kryterium językowe zawyżyło liczbę Polaków (Zaborski 1937; Tomaszewski 1985; Eberhardt 1996, 2006; Chałupczak, Browarek 1998). Lepszym sposobem szacunkowego określenia narodowości - choć często również zawodnym i obarczonym trudnymi do uniknięcia błędami oraz uproszczeniami - była deklaracja wyznania, która w okresie międzywojennym, zwłaszcza w województwach wschodniej Polski, lepiej oddawała narodowość mieszkańców niż kryterium językowe.

Ponadto jedną z wad spisów powszechnych jest zakładanie jednoznaczności podziałów narodowościowych, co uniemożliwia określenie liczebności środowisk o pośredniej lub kształtującej się dopiero świadomości narodowej, które z pewnością w ówczesnej Polsce istniały. Część ludności określała się w kategoriach regionalnych (np. „tutejsi”, Poleszucy, Huculi, Łemkowie, Ślązacy). Było to spowodowane wieloma czynnikami, głównie niechęcią do jednoznacznej deklaracji narodowościowej, słabo wykształconą świadomością narodową, wpływem wielokulturowych pograniczy etnicznych, ale także postępującym

${ }^{2}$ Podczas spisu w 1931 roku język ukraiński jako ojczysty zadeklarowało 3221,9 tys. osób, natomiast język ruski 1219,6 tys. osób, co świadczyło o dużej popularności określeń Rusin, ruski, rusiński wśród ówczesnych mieszkańców południowo-wschodniej Polski. 
procesem krystalizowania się nowych tożsamości narodowych. Z powodu braku możliwości określenia liczebności takich grup, w praktyce przypisywano je do poszczególnych narodowości zamieszkujących Polskę, co często prowadziło do błędów. Oprócz tego typowe dla wielu mieszkańców ówczesnej Polski złe warunki życia, niski poziom oświaty (często wręcz analfabetyzm), niewielka świadomość polityczna i narodowa, ułatwiały manipulacje podczas spisów ludności i zaniżanie liczebności grup mniejszościowych (Barwiński 2013).

J. Tomaszewski (1985) na podstawie informacji dotyczących metod fałszowania wyników na wszystkich szczeblach ich obróbki oraz porównania danych dotyczących deklaracji języka ojczystego i wyznania skorygował wynik spisu powszechnego z 1931 roku oraz dokonał własnych szacunków ówczesnej struktury narodowościowej Polski. Całą ludność deklarującą jako ojczysty język ruski zaliczył do mówiącej po ukraińsku. Ponadto 707 tys. osób, które w województwie poleskim zadeklarowały jako ojczysty język ,tutejszy” (według oficjalnych wyników zostali uznani za ,innych”), z powodu jednoczesnych deklaracji wyznania prawosławnego oraz na ogół wyższego wśród Ukraińców niż Białorusinów stopnia świadomości narodowej, w 3/4 uznał za Białorusinów, a w 1/4 za Ukraińców. Dalsze korekty wynikały z porównania deklaracji języka ojczystego i wyznania, a szczególnie liczby osób, które przy języku polskim podały wyznanie prawosławne, greckokatolickie lub mojżeszowe. Według danych spisu liczba wyznawców prawosławia i grekokatolicyzmu była o ok. 800 tys. wyższa od łącznej liczby Ukraińców, Białorusinów i Rosjan. Ponadto według oficjalnych danych w okresie zaledwie 10 lat (1921-1931) nastąpił bardzo duży, 35\% wzrost liczby Polaków-grekokatolików, których według danych spisowych miało być w południowo-wschodniej Polsce aż 487 tys. Trudno zgodzić się z wiarygodnością tych liczb. J. Tomaszewski (1985), optując za wyższością deklaracji wyznaniowych nad językowymi przy szacowaniu struktury narodowościowej uważał, że osoby wyznania prawosławnego, greckokatolickiego i mojżeszowego w zdecydowanej większości nie były narodowości polskiej. Z kolei P. Eberhardt (2006) zwracał uwagę, że wielu Ukraińców, Białorusinów i Żydów mogło deklarować język polski jako ojczysty, podkreślając w ten sposób lojalność wobec państwa polskiego.

Największe różnice między oficjalnymi wynikami spisu z 1931 roku a szacunkami opracowanymi przez J. Tomaszewskiego (1985) dotyczyły liczby Ukraińców, Białorusinów i Żydów, wynikały zarówno z bezpośrednich fałszerstw (zwłaszcza zaniżania liczby Ukraińców), jak i z różnego traktowania ludności deklarującej język ojczysty „tutejszy” lub polski, przy jednoczesnej deklaracji wyznania prawosławnego, greckokatolickiego lub mojżeszowego (tab. 2).

O ile bezpośrednie fałszerstwa podczas spisu w 1931 roku są faktem bezspornym, o tyle szacunki J. Tomaszewskiego również są dyskusyjne i kontrowersyjne, zwłaszcza całkowicie sztuczne uznanie, że 3/4 spośród deklarujących język „tutejszy” to Białorusini, a pozostali to Ukraińcy. Znaczna część ówczes- 
nych mieszkańców województwa poleskiego była słabo wykształconą i żyjącą w izolacji ludnością wiejską o bardzo niskim i dopiero rodzącym się poczuciu świadomości narodowej, niekoniecznie takim, za jakim optował J. Tomaszewski. Także arbitralne uznanie wszystkich polskojęzycznych wyznawców prawosławia, grekokatolicyzmu, a zwłaszcza judaizmu za ludność niepolską, z pewnością nie odpowiadało rzeczywistej strukturze narodowościowej. Z różnych przyczyn, także zachodzących procesów akulturacji i asymilacji do polskości, część osób pochodzenia ukraińskiego, białoruskiego czy żydowskiego - zwłaszcza deklarujących język polski jako ojczysty - mogła posiadać polską świadomość narodową i z pełnym przekonaniem podawać ją podczas spisu powszechnego.

Tabela 2

Struktura narodowościowa Polski w 1931 roku

\begin{tabular}{|l|c|c|c|c|}
\hline \multirow{2}{*}{ Narodowość } & \multicolumn{4}{|c|}{ Struktura narodowościowa } \\
\cline { 2 - 5 } & \multicolumn{3}{|c|}{ według danych spisu } & \multicolumn{2}{c|}{$\begin{array}{c}\text { według szacunków } \\
\text { J. Tomaszewskiego }\end{array}$} \\
\cline { 2 - 5 } & w tys. & $\begin{array}{c}\text { w \% ogółu } \\
\text { ludności }\end{array}$ & w tys. & $\begin{array}{c}\text { w \% ogółu } \\
\text { ludności }\end{array}$ \\
\hline Polacy & 21993 & 68,9 & 20644 & 64,7 \\
\hline Ukraińcy & 4442 & 13,9 & 5114 & 16,0 \\
\hline Żydzi & 2733 & 8,6 & 3114 & 9,8 \\
\hline Białorusini & 990 & 3,1 & 1954 & 6,1 \\
\hline Niemcy & 741 & 2,3 & 780 & 2,4 \\
\hline Rosjanie & 139 & 0,4 & 139 & 0,4 \\
\hline Litwini & 83 & 0,3 & 83 & 0,3 \\
\hline Czesi & 38 & 0,1 & 38 & 0,1 \\
\hline Inni & 718 & 2,3 & 11 & 0,1 \\
\hline Niepodana & 39 & 0,1 & - & - \\
\hline
\end{tabular}

Źródło: opracowanie własne na podstawie: Statystyka Polski (1938), Drugi Powszechny Spis Ludności z dnia 9 XII 1931 roku, seria C, z. 94a, J. Tomaszewski (1985, s. 35).

Inni naukowcy również krytycznie podchodzili do oficjalnych wyników spisu z 1931 roku i dokonywali własnych szacunków. Ich wyniki najczęściej były zbliżone do opracowań J. Tomaszewskiego, zwłaszcza w kwestii liczby Ukraińców i Białorusinów (Chałupczak, Browarek 1998). Zaniżanie liczby Ukraińców dotyczyło nie tylko Galicji Wschodniej, ale także Podlasia, gdzie w 1931 roku, według oficjalnych danych, zaledwie ok. 3 tys. osób zadeklarowało ukraiński jako język ojczysty, a pozostała ludność prawosławna - białoruski. Jeden z najwybitniejszych znawców sytuacji narodowościowej wschodniej Polski początku XX wieku, L. Wasilewski (1927), uznawał południowo- 
-wschodnią część powiatu bielskiego za ziemie ukraińskie, również A. Krysiński (1937), zgadzając się z L. Wasilewskim, określił całą ludność prawosławną żyjącą na obszarze wschodniej części powiatu bielskiego za „niewątpliwie Ukraińców". Liczebność mniejszości ukraińskiej w województwie białostockim w latach 30. XX wieku, wbrew wynikom spisu, można szacować na ponad 80 tys. osób (Barwiński 2004).

Duże rozbieżności dotyczyły także liczby Litwinów, których spis wykazał 83 tys., natomiast B. Makowski (1986) szacował ich ówczesną liczebność na 200 tys., a H. Chałupczak i T. Browarek (1998) na 180 tys. osób. Spis powszechny został przeprowadzony podczas nadal trwającego sporu polsko-litewskiego o Wilno i zamieszkane przez Litwinów przygraniczne powiaty. Ujawnienie rzeczywistej liczby Litwinów na spornym terytorium z pewnością było niekorzystne $z$ punktu widzenia polskich władz. Nie opracowano jednak szczegółowych szacunków dotyczących liczby mniejszości litewskiej, ponieważ miała ona relatywnie niewielkie znaczenie demograficzne w strukturze narodowościowej ówczesnej Polski. Ponadto z powodu przynależności Litwinów do Kościoła rzymskokatolickiego statystyka wyznaniowa w tym przypadku była nieprzydatna.

Wyniki spisu z roku 1931 - podobnie jak i 1921 - nie oddały rzeczywistej struktury narodowościowej Polski. Zaniżyły liczebność mniejszości narodowych, zwłaszcza Ukraińców i Białorusinów, prawdopodobnie także Litwinów, ponadto z powodu sformułowania pytania o język ojczysty, w ogóle nie wykazały wielu faktycznie zamieszkujących Polskę narodowości (m.in. Słowaków, Ormian, Tatarów, Karaimów, Romów). Jednak szacunki J. Tomaszewskiego (1985) również wypaczają ówczesną liczebność mniejszości, z kolei zawyżając ich potencjał demograficzny, zwłaszcza społeczności żydowskiej i białoruskiej, a w dużo w mniejszym stopniu, także ukraińskiej.

\section{Spis w 1946 roku}

Pierwszy po wojnie, tzw. sumaryczny spis ludności (nieimienny, z ograniczoną liczbą pytań), przeprowadzono według stanu z 14 lutego 1946 roku. Zawarto w nim m.in. pytanie o narodowość. Jednak jego wyniki z wielu różnych przyczyn są mało wiarygodne i nieprzydatne do analizy ówczesnej struktury narodowościowej Polski (tab. 3). Był on zorganizowany głównie w celu określenia strat ludnościowych wywołanych drugą wojną światową i okupacją hitlerowską, ustalenia aktualnej struktury, liczebności i rozmieszczenia Polaków oraz ustalenia liczebności i rozmieszczenia podlegającej wysiedleniu ludności niemieckiej.

Spis przeprowadzono w bardzo niestabilnej, dynamicznej sytuacji demograficznej, podczas trwających przesiedleń ludności, zarówno wysiedleń Niemców, Ukraińców, Łemków, Białorusinów, Litwinów, jak i przesiedleń ludności polskiej i żydowskiej z ziem zajętych przez ZSRR. Ponadto w kwestionariuszu 
spisowym wyróżniono jedynie Polaków, Niemców i ,innych” oraz osoby, w stosunku do których toczyły się postępowania rehabilitacyjne lub weryfikacyjne, dlatego nie dał on żadnych informacji na temat ówczesnej liczebności np. Żydów, Ukraińców czy Białorusinów ${ }^{3}$. Jest także bardzo prawdopodobne, że osoby z narodowości podlegających wówczas przesiedleniom (głównie Niemcy i Ukraińcy), obawiając się deportacji, mogły świadomie deklarować narodowość polską. Spis nie objął osób zatrudnionych przez wojska radzieckie (w dużym stopniu Niemców), a w podziale na narodowości nie uwzględniono w nim żołnierzy (ponad 300 tys. osób). Nie objął także całego terytorium Polski, z powodu działalności UPA nie został przeprowadzony w części Bieszczadów. Nie opublikowano jego wyników w odniesieniu do gmin i powiatów, co dodatkowo utrudniało ocenę ich wiarygodności. Jest bardzo prawdopodobne, że liczebność Niemców i „,innych” była zaniżona, a wyniki tego spisu są dalekie od rzeczywistej struktury narodowościowej Polski w 1946 roku (Olejnik 2003; Gawryszewski 2005).

Tabela 3

Wyniki sumarycznego spisu ludności z 1946 roku dotyczące narodowości

\begin{tabular}{|c|c|c|c|c|}
\hline \multirow{2}{*}{$\begin{array}{c}\text { Ludność } \\
\text { ogółem }\end{array}$} & \multicolumn{3}{|c|}{ Narodowości } & $\begin{array}{c}\text { Postępowanie } \\
\text { rehabilitacyjne } \\
\text { lub } \\
\text { weryfikacyjne }\end{array}$ \\
\hline 23929757 & 20520178 & 2228830 & 399526 & 417431 \\
\hline
\end{tabular}

Źródło: opracowanie własne na podstawie: Statystyka Polski... (1947).

W pięciu kolejnych spisach ludności (1950, 1960, 1970, 1978, 1988) nie uwzględniano pytań o narodowość, język ojczysty i wyznanie. Władze komunistyczne uznały, że po zmianach granic i przesiedleniach ludności Polska przekształciła się w kraj jednolity etnicznie, a problematyka mniejszości narodowych stała się marginalna. Liczebność ludności niepolskiej była określana jedynie na podstawie różnego rodzaju, mniej lub bardziej wiarygodnych, szacunków. W urzędowych kwestionariuszach rubryka dotycząca narodowości zachowała się do końca lat 80 . ubiegłego wieku w ankietach personalnych składanych w celu otrzymania dokumentu tożsamości lub paszportu, lecz dane te pozostawały w wyłącznej gestii Ministerstwa Spraw Wewnętrznych, które jednak formalnie nie opracowywało analiz struktury narodowościowej (Sobczyński 2012). Kolejne spisy, w których zadano pytanie o narodowość, przeprowadzono dopiero kilkanaście lat po demokratyzacji życia politycznego i społecznego, w roku 2002 oraz 2011.

${ }^{3}$ P. Eberhardt (2010) na podstawie własnych wyliczeń oszacował ówczesną liczbę Ukraińców na 220,2 tys., a Białorusinów na 116,5 tys., natomiast A. Gawryszewski (2005) podał, że w kategorii ,inni” Ukraińcy stanowili ok. 162 tys. osób. 


\section{Spis w 2002 roku}

Pomimo niewątpliwego występowania w drugiej połowie XX wieku procesów asymilacyjnych, w tym polonizacyjnych wśród mniejszości narodowych, nie znajdowały one odzwierciedlenia $\mathrm{w}$ różnorakich szacunkach dotyczących ich liczebności, według których liczba przedstawicieli tzw. tradycyjnych mniejszości narodowych w Polsce, począwszy od lat 50. XX wieku, albo utrzymywała się na podobnym poziomie, albo nieznacznie, choć systematycznie rosła. Natomiast upowszechnienie na początku lat 90. XX wieku szacunkowych danych dotyczących liczebności członków bardzo licznie powstających wówczas organizacji narodowościowych, dalszy brak oficjalnych danych spisowych oraz przekonanie wielu badaczy, że w okresie PRL władze celowo zaniżały liczebność ludności niepolskiej (m.in. Sakson 1991; Hołuszko 1993; Eberhardt 1996; Kurcz 1997; Chałupczak, Browarek 1998; Sobczyński 2000), spowodowały wyraźny wzrost szacowanej liczebności poszczególnych mniejszości narodowych i etnicznych.

Dopiero przeprowadzony w 2002 roku spis powszechny, zawierający pytanie dotyczące przynależności narodowej oraz języka „używanego w kontaktach domowych", po raz pierwszy od kilkudziesięciu lat przedstawił oficjalną liczebność oraz rozmieszczenie społeczności niepolskich na terytorium Rzeczypospolitej (tab. 4).

Pytanie o narodowość sformułowano w najprostszy, ale jednocześnie bardzo bezpośredni sposób - „do jakiej narodowości się Pan(i) zalicza?”4. Było to wyraźne nawiązanie do spisu z 1921 roku, a jednocześnie zachowanie zgodności z normami europejskimi oraz kryteriami etniczności dominującymi współcześnie w literaturze przedmiotu. Pytanie miało charakter otwarty oraz formę subiektywnej deklaracji, nie było żadnego spisu narodowości do wyboru, nie było także możliwości deklarowania złożonych, stopniowalnych tożsamości.

Spis wykazał niewielką liczebność ludności niepolskiej - inną niż polska narodowość zadeklarowało zaledwie 471,5 tys. osób ${ }^{5}$ (1,23\%), z tego 444,6 tys. posiadało obywatelstwo polskie $(1,16 \%)$, więc zgodnie $\mathrm{z}$ aktualnym stanem prawnym tylko te osoby można traktować jako członków mniejszości narodowych i etnicznych w Polsce. Liczby te potwierdziły powszechną tezę, że Polska należy obecnie do najbardziej homogenicznych narodowościowo państw

\footnotetext{
${ }^{4} \mathrm{~W}$ formularzu spisowym narodowość zdefiniowano jako ,,deklaratywną (opartą na subiektywnym odczuciu) cechę indywidualną każdego człowieka, wyrażającą jego związek emocjonalny (uczuciowy), kulturowy lub genealogiczny (ze względu na pochodzenie rodziców) z określonym narodem".

${ }^{5}$ Wszystkie dane liczbowe dotyczące wyników spisu z 2002 roku zostały podane na podstawie danych GUS (2008), Wyniki Narodowego Spisu Powszechnego Ludności i Mieszkań 2002 w zakresie deklarowanej narodowości oraz języka używanego $w$ domu (15.07.2008).
} 
w Europie ${ }^{6}$. Jednak mimo małej liczebności mniejszości, struktura narodowościowa Polski okazała się niezwykle zróżnicowana i jednocześnie rozdrobniona. W trakcie spisu wyodrębniono aż 109 różnych mniejszości, zarówno narodowych, etnicznych, jak i etniczno-regionalnych ${ }^{7}$.

Nie ustalono przynależności narodowej aż 774,9 tys. osób, dotyczyło to jednak w zdecydowanej większości osób nieobecnych w trakcie spisu w miejscu zamieszkania. W bezpośredniej rozmowie z rachmistrzem deklaracji narodowościowej odmówiło ok. 40 tys. osób (Nijakowski, Łodziński 2003; Łodziński 2006). Można tylko przypuszczać, że byli to głównie członkowie mniejszości narodowych. Ponadto 4,2 tys. osób zadeklarowało niepolską narodowość, jednak nie precyzując jaką. Najbardziej zaskakujących wynikiem spisu była duża liczba deklaracji narodowości śląskiej - 173,2 tys. Ślązacy okazali się najliczniejszą grupą mniejszościową. Kolejnym, charakterystycznym rezultatem było wykazanie bardzo małej liczebności tzw. tradycyjnych mniejszości narodowych, zdecydowanie odbiegającej in minus od wcześniejszych szacunków. Różnica między szacunkami a wynikami spisu była nawet dziesięciokrotna. Dotyczyło to mniejszości relatywnie licznych, m.in. Ukraińcy, Białorusini, Łemkowie, i liczebnie marginalnych - Tatarzy, Ormianie, Czesi czy Żydzi (tab. 4).

Tak duże różnice między szacunkami z lat 90 . XX wieku a wynikami spisu mogą wskazywać na dwie możliwości: wcześniejsze zawyżenie rzeczywistej liczebności poszczególnych mniejszości lub jej zaniżenie poprzez procedury zastosowane $\mathrm{w}$ trakcie spisu powszechnego. Wydaje się, że oba te czynniki zadziałały jednocześnie.

Można przyjąć, że wartości liczbowe podawane w różnego rodzaju szacunkach dotyczących liczebności mniejszości narodowych i etnicznych w Polsce, zwłaszcza w latach 90. XX wieku, były zawyżone, m.in. z powodu niedoceniania intensywności procesów asymilacji i akulturacji, zarówno w okresie PRL, jak i w okresie demokratyzacji życia społeczno-politycznego w latach 90. XX wieku. Szacunki te dotyczyły ogółu osób wywodzących się ze środowisk ludności niepolskiej. Zarówno osób o bardzo silnej tożsamości narodowej, jak i „pochodzenia” niepolskiego, o złożonej, stopniowalnej tożsamości narodowej, a także osób, które w ciągu ostatnich kilkudziesięciu czy kilkunastu lat w dużym stopniu zatraciły poczucie odrębności narodowej i obecnie uważają się za Polaków, a nie członków mniejszości narodowych.

${ }^{6}$ Państwo uznawane jest za jednolite etnicznie, jeżeli mniejszości narodowe i etniczne nie stanowią więcej niż 5\% obywateli, w przypadku Polski w 2002 roku ten udział był prawie pięciokrotnie mniejszy.

${ }^{7}$ Spośród 109 wykazanych w trakcie spisu narodowości, pięć najliczniejszych (śląska, niemiecka, białoruska, ukraińska i romska) stanowiło aż 88,7\% ogółu deklaracji niepolskiej narodowości, a łącznie z pięcioma kolejnymi pod względem liczebnym mniejszościami (rosyjską, litewską, łemkowską, kaszubską, słowacką) reprezentowało aż 96,4\% wszystkich osób deklarujących podczas spisu niepolską narodowość (Szczygielski 2006). 
Tabela 4

Struktura narodowościowa Polski na przełomie XX i XXI wieku - porównanie szacunków z lat 90. XX wieku oraz wyników spisu powszechnego z 2002 roku

\begin{tabular}{|c|c|c|c|}
\hline \multirow[b]{2}{*}{ Narodowość } & \multirow{2}{*}{$\begin{array}{l}\text { Szacunkowa } \\
\text { liczebność } \\
\text { sprzed spisu } \\
\text { (w tys.) }\end{array}$} & \multicolumn{2}{|c|}{$\begin{array}{c}\text { Wyniki spisu powszechnego z } 2002 \text { roku } \\
\text { (w tys.) }\end{array}$} \\
\hline & & ogółem & $\begin{array}{c}\text { posiadający } \\
\text { polskie } \\
\text { obywatelstwo }\end{array}$ \\
\hline Polacy & - & 36983,7 & 36895,2 \\
\hline Ślązacy & - & 173,2 & 172,7 \\
\hline Niemcy & $300-360$ & 152,9 & 147,1 \\
\hline Białorusini & $200-300$ & 48,7 & 47,6 \\
\hline Ukraińcy & $150-300$ & 31,0 & 27,2 \\
\hline Romowie & $15-25$ & 12,9 & 12,7 \\
\hline Rosjanie & 10-17 & 6,1 & 3,2 \\
\hline Łemkowie & 50-80 & 5,9 & 5,8 \\
\hline Litwini & $9-25$ & 5,8 & 5,6 \\
\hline Kaszubi & $370-500$ & 5,1 & 5,1 \\
\hline Słowacy & $10-25$ & 2,0 & 1,7 \\
\hline Wietnamczycy & - & 1,8 & 0,4 \\
\hline Francuzi & - & 1,6 & 1,0 \\
\hline Amerykanie & - & 1,5 & 1,0 \\
\hline Grecy & - & 1,4 & 0,8 \\
\hline Żydzi & $5-15$ & 1,1 & 1,1 \\
\hline Bułgarzy & - & 1,1 & 0,4 \\
\hline Ormianie & $5-15$ & 1,1 & 0,3 \\
\hline Czesi & $1-5$ & 0,8 & 0,4 \\
\hline Tatarzy & $2,5-5$ & 0,5 & 0,45 \\
\hline
\end{tabular}

Źródło: opracowanie własne na podstawie M. Barwiński (2006, s. 348) oraz danych GUS.

$\mathrm{Na}$ wyniki wpływ miała także metoda przeprowadzenia spisu. W 2002 roku po raz pierwszy od kilkudziesięciu lat zadano pytanie o narodowość, formułowane bardzo bezpośrednio, jednoznacznie. Taka nowość z pewnością wywołała konsternację wśród części ludności niepolskiej, co mogło w efekcie prowadzić do zatajenia prawdziwego pochodzenia etnicznego lub do świadomego wyboru narodowości polskiej w przypadku niewielkiego poczucia tożsamości z własną grupą mniejszościową.

Należy również pamiętać, że spis powszechny jest postrzegany jako przedsięwzięcie administracyjne władz państwowych, co w kontekście negatywnych 
doświadczeń historycznych niektórych grup narodowościowych (np. Niemców, Ukraińców, Łemków) może powodować niechęć ujawniania niepolskiej tożsamości, zwłaszcza w bezpośredniej rozmowie z rachmistrzem. Czynnikiem, który mógł wpłynąć na wyniki, był brak anonimowości, zwłaszcza w środowiskach wiejskich i małomiasteczkowych. Nie bez znaczenia dla tak niewielkiej, wykazanej w trakcie spisu liczebności osób niepolskiej narodowości, był nadal utrzymujący się wśród polskiego społeczeństwa niewielki poziom tolerancji oraz negatywne stereotypy, co mogło powodować niechęć do deklaracji m.in. narodowości romskiej, ukraińskiej czy żydowskiej.

Spis powszechny w 2002 roku, wykazując niewielką liczebność mniejszości narodowych, $\mathrm{z}$ jednej strony ukazal skalę przeszacowania oraz natężenie procesów polonizacyjnych, które zaszły w ciągu ostatniego półwiecza, z drugiej zaś, z powodu przyjętej metody przeprowadzenia spisu i konstrukcji pytania oraz uwarunkowań społecznych, zaniżył liczebność mniejszości narodowych w Polsce (m.in. Babiński 2004; Łodziński 2005, 2006; Adamczuk, Łodziński 2006; Barwiński 2006; Chałupczak 2006). Jego wyniki, podobnie jak wszystkich tego typu spisów w państwach demokratycznych, opierały się wyłącznie na subiektywnych deklaracjach obywateli. Nie oddały one w pełni współczesnej struktury narodowościowej Polski, nie można ich jednak negować. Nie tyle pokazały rzeczywistą liczebność poszczególnych mniejszości, ile stan świadomości narodowej niepolskich narodowości. Uzyskane w trakcie tego spisu dane należy traktować jako wartości minimalne, jako liczbę osób o silnie ugruntowanej niepolskiej tożsamości narodowej.

\section{Spis w 2011 roku}

Przeprowadzony niespełna dekadę później, wiosną 2011 roku, kolejny spis ludności dawał nadzieję na weryfikację wcześniejszych danych i przedstawienie zmian struktury narodowościowej Polski na początku XXI wieku. Niestety, w obu spisach ludności (2002 i 2011) zastosowano całkowicie odmienne procedury i metody pozyskiwania danych oraz przedstawiania rezultatów.

Spis z 2011 roku został podzielony na - różniące się liczbą pytań w formularzu - tzw. badanie pełne oraz dużo obszerniejsze badanie reprezentacyjne, którym objęto mieszkańców $20 \%$ wylosowanych gospodarstw domowych (ponad 8 mln osób), z zamiarem uogólnienia danych na całą populację. Kolejnymi nowościami były: możliwość indywidualnego dokonania spisu za pomocą Internetu, zadeklarowania podwójnej tożsamości narodowej oraz (tylko w badaniu reprezentacyjnym) udzielenia odpowiedzi na pytania dotyczące wyznania i języka ojczystego. Dane zbierano ze zróżnicowanych źródeł: z rejestrów państwowych, z samospisu internetowego, wywiadu telefonicznego prowadzonego przez ankietera statystycznego oraz z wywiadu rejestrowanego na urządzeniu elektronicznym prowadzonego przez rachmistrza spisowego. Nie było natomiast, tak jak podczas wcześniejszych spisów, bezpośrednich wizyt rachmistrza 
spisowego we wszystkich mieszkaniach. Taka forma przeprowadzenia spisu spowodowana była głównie oszczędnościami finansowymi (Barwiński 2014).

$\mathrm{Z}$ powodu niewielkiego zainteresowania samospisem internetowym ${ }^{8} \mathrm{i}$ braku wizyty rachmistrza spisowego $\mathrm{w}$ wielu mieszkaniach, spis z 2011 roku nie wypełnił co najmniej dwóch, spośród czterech podstawowych kryteriów współczesnych spisów ludności. Nie spełniał kryterium powszechności ${ }^{9}$ i bezpośredniości (nie wszystkie odpowiedzi zostały uzyskane bezpośrednio od osoby spisywanej). Spełniał jedynie kryterium jednoczesności, natomiast dyskusyjne jest, czy przy założeniu braku powszechności spełniał kryterium imienności.

W formularzach spisowych w całkowicie nowy sposób sformułowano pytania etniczne. Co prawda, podstawowe pytanie było identyczne jak przed dekadą, czyli „Jaka jest Pana(i) narodowość?”, to jednak nie było to pytanie otwarte, lecz zawierało listę 14 narodowości (polską oraz 13 ułożonych alfabetycznie mniejszości wyszczególnionych w ustawie ${ }^{10}$ ) oraz opcję ,inna”, która z kolei zawierała wykaz aż 177 narodowości, w tym m.in. śląską, kaszubską, mazurską, rusińską, bojkowską, huculską. Jeżeli ktoś nadal nie mógł znaleźć narodowości, która byłaby zgodna $\mathrm{z}$ jego poczuciem tożsamości, to istniała możliwość wpisania dowolnej identyfikacji spoza listy.

Zupełnie nowe było natomiast kolejne pytanie, umieszczone po raz pierwszy w polskich spisach ludności pod wpływem sugestii liderów organizacji mniejszości narodowych: „Czy odczuwa Pan(i) przynależność także do innego narodu lub wspólnoty etnicznej?”. Umieszczenie tego pytania w formularzu spisowym było odpowiedzią na apele środowisk wywodzących się spośród niepolskich narodowości, by osoby o złożonej, podwójnej tożsamości narodowej miały szanse to wyrazić. W praktyce oznaczało to możliwość zadeklarowania dwóch narodowości. Liczebność poszczególnych mniejszości narodowych i etnicznych została ustalona na podstawie liczby deklaracji narodowościowych, wyrażonych jako odpowiedź na pierwsze lub drugie ,pytanie etniczne”. W sytuacji, gdy w pierwszym pytaniu osoba zadeklarowała narodowość polską, a równocześnie w drugim pytaniu przynależność do mniejszości narodowej lub etnicznej, została przypisana jej zadeklarowana narodowość niepolska (mniejszościowa), według odpowiedzi na drugie pytanie. Natomiast w sytuacji, gdy osoba zadeklarowała przynależność do dwóch społeczności mniejszościowych, została przypisana jej

${ }^{8} \mathrm{Z}$ możliwości samodzielnego wypełnienia formularza spisowego za pomocą Internetu skorzystało zaledwie $12 \%$ populacji (ok. 4,5 mln osób).

${ }^{9}$ GUS podkreśla, że spis ludności z 2011 roku był powszechny, gdyż objął całą podlegającą badaniu ludność poprzez zebranie danych z rejestrów administracyjnych. Dla wielu zakresów tematycznych objętych spisem jest to prawdą, natomiast według autora na potrzeby określenia struktury narodowościowej (a tylko tego zakresu tematycznego spisu dotyczy artykuł), nie można mówić o powszechności spisu, ponieważ danych dotyczących tożsamości narodowej nie można było uzyskać z rejestrów administracyjnych.

${ }^{10}$ Dotyczy Ustawy o mniejszościach narodowych $i$ etnicznych oraz o języku regionalnym (Dz.U., 2005, nr 17, poz. 141). 
narodowość zgodnie z odpowiedzią na pierwsze pytanie. Taki sposób zaliczania osób do poszczególnych mniejszości narodowych i etnicznych był w Polsce nowatorski, zwłaszcza zasada nadrzędności deklaracji przynależności do mniejszości nad polską tożsamością narodową.

Struktura narodowościowa i językowa została ostatecznie ustalona na podstawie danych pozyskanych w badaniu reprezentacyjnym (objęło losowo wybrane $20 \%$ gospodarstw domowych), w samospisie internetowym oraz z uwzględnieniem wyników badania pełnego przeprowadzonego wśród wszystkich mieszkańców 86 dobranych celowo gmin, w których przynależność do mniejszości narodowej lub etnicznej zadeklarowało w 2002 roku minimum 10\% mieszkańców. Z wykorzystaniem tych trzech metod zbierania informacji GUS ustalił liczebność mniejszości narodowych i etnicznych dla całego kraju oraz poszczególnych jednostek administracyjnych.

Zatem struktura narodowościowa ludności Polski w 2011 roku, odmiennie niż podczas wcześniejszych spisów, została opracowana w głównej mierze na podstawie informacji pozyskanych metodą losową wśród mieszkańców zaledwie $20 \%$ gospodarstw domowych oraz wykonanych ekstrapolacji i szacunków, a nie na podstawie bezpośredniej rozmowy rachmistrza z respondentem podczas spisu o charakterze powszechnym. Taki sposób przeprowadzenia spisu, pozyskiwania danych i określania struktury narodowościowej w bardzo istotny sposób ogranicza wartość poznawczą uzyskanych wyników (Barwiński 2014).

Podczas spisu w 2011 roku narodowość inną niż polska (w bardzo różnych konfiguracjach) zadeklarowało 1 467,7 tys. osób (3,81\%). Z możliwości wyrażenia podwójnej tożsamości skorzystało aż 917,3 tys. osób, w tym zdecydowana większość (871,4 tys.) wykazała zarówno polską, jak i inną tożsamość narodowo-etniczną, w znakomitej większości polską na miejscu pierwszym (788,1 tys.). Wszystkie te osoby (bez względu na to, na którym miejscu umieściły narodowość polską) zostały przypisane do mniejszości narodowych lub etnicznych, co nie zawsze musiało być zgodne z ich intencjami. Taki sposób obliczania struktury narodowościowej okazał się kluczowy dla ponad trzykrotnego wzrostu liczebności mniejszości narodowych i etnicznych w Polsce w latach 2002-2011. Natomiast wyłącznie niepolską narodowość zadeklarowało 596,3 tys. osób (1,55\%), w tym 45,9 tys. identyfikowało się z dwoma niepolskimi narodowościami. Wobec 521,5 tys. osób $(1,35 \%)$ nie ustalono przynależności narodowej. W większości dotyczyło to osób nieprzebywających w trakcie spisu w miejscu zamieszkania, w tym przebywających co najmniej od 12 miesięcy za granicą. Dzięki możliwości wyboru narodowości z zamieszczonego w formularzu obszernego słownika etnonimów lub swobodnego zapisu dowolnej deklaracji tożsamości ogółem zanotowano ponad 200 różnorodnych niepolskich identyfikacji narodowych i etnicznych, regionalnych i lokalnych ${ }^{11}$.

\footnotetext{
${ }^{11}$ Na podstawie opracowania GUS (2013), Ludność. Stan i struktura demograficzno-
} -spoteczna (09.04.2013). 
Spośród deklaracji narodowościowych zdecydowanie najliczniejsze dotyczyły odrębności etnicznej społeczności regionalnych - Ślązaków i Kaszubów, z tym, że zwłaszcza w przypadku Kaszubów, były one wyrażane głównie $\mathrm{w}$ drugim pytaniu i w dużym stopniu wiązały się $\mathrm{z}$ jednoczesnym odczuwaniem polskiej tożsamości narodowej. Pod względem liczebnym Ślązacy całkowicie zdominowali strukturę mniejszości narodowych i etnicznych w Polsce. Deklaracje narodowości śląskiej były liczniejsze niż wszystkie pozostałe niepolskie identyfikacje etniczno-narodowe i to we wszystkich „kategoriach” (tab. 5).

Tabela 5

Struktura narodowościowa Polski na podstawie wyników spisu z 2011 roku $^{a}$

\begin{tabular}{|l|r|r|r|r|c|}
\hline \multirow{2}{*}{ Narodowość } & \multicolumn{5}{|c|}{ Deklarowana narodowość (w tys.) } \\
\cline { 2 - 6 } & ogółem $^{b}$ & $\begin{array}{c}\text { jako } \\
\text { pierwsza }\end{array}$ & $\begin{array}{c}\text { W tym jako } \\
\text { jedyna }\end{array}$ & jako druga & $\begin{array}{c}\text { Wspólnie } \\
\text { z polską }\end{array}$ \\
\hline Polacy & 37393,7 & 37310,3 & 36522,2 & 83,3 & x \\
\hline Ślązacy & 846,7 & 435,8 & 375,6 & 411,0 & 430,8 \\
\hline Kaszubi & 232,6 & 17,7 & 16,4 & 214,8 & 215,8 \\
\hline Niemcy & 147,8 & 74,5 & 44,5 & 73,4 & 63,8 \\
\hline Ukraińcy & 51,0 & 38,4 & 27,6 & 12,6 & 20,8 \\
\hline Białorusini & 46,8 & 36,4 & 30,2 & 10,4 & 15,6 \\
\hline Romowie & 17,1 & 12,6 & 9,9 & 4,5 & 7,0 \\
\hline Rosjanie & 13,1 & 8,2 & 5,2 & 4,8 & 7,1 \\
\hline Amerykanie & 11,8 & 1,2 & 0,8 & 10,6 & 10,8 \\
\hline Łemkowie & 10,5 & 7,1 & 5,6 & 3,4 & 3,6 \\
\hline Anglicy & 10,5 & 1,6 & 1,2 & 8,9 & 9,1 \\
\hline Włosi & 8,6 & 1,7 & 0,9 & 7,0 & 7,5 \\
\hline Francuzi & 8,0 & 1,5 & 1,1 & 6,5 & 6,8 \\
\hline Litwini & 7,9 & 5,6 & 4,8 & 2,3 & 3,0 \\
\hline Żydzi & 7,5 & 2,5 & 1,6 & 5,0 & 5,4 \\
\hline Wietnamczycy & 4,0 & 3,6 & 2,9 & 0,4 & 1,1 \\
\hline Hiszpanie & 4,0 & 0,5 & 0,4 & 3,5 & 3,4 \\
\hline Holendrzy & 3,9 & 0,9 & 0,5 & 3,1 & 3,3 \\
\hline Ormianie & 3,6 & 3,0 & 2,0 & 0,7 & 1,5 \\
\hline Grecy & 3,6 & 1,1 & 0,7 & 2,5 & 2,9 \\
\hline
\end{tabular}

Objaśnienia: ${ }^{a}$ dotyczy ogółu osób, zarówno posiadających, jak i nieposiadających polskiego obywatelstwa; ${ }^{b}$ dane nie sumują się, odpowiedzi pochodzą z dwóch pytań.

Źródło: opracowanie własne na podstawie danych GUS (2013), Ludność. Stan i struktura demograficzno-społeczna. 
Było to potwierdzenie ich dominującej pozycji z poprzedniego spisu w 2002 roku, jednak tak imponujący wzrost liczebności (ze 173,2 tys. do 846,7 tys. osób) w trakcie niecałej dekady był w głównej mierze konsekwencją zmian w metodzie przeprowadzania spisu (411 tys. osób zadeklarowało narodowość śląską w drugim pytaniu), aktywności śląskich organizacji oraz medialnego nagłośnienia i upolitycznienia kwestii narodowości śląskiej. Mimo to wyniki spisu z 2011 roku wyraźnie wskazują na wzrost poczucia odrębności etnicznej grup regionalnych, nie tylko Ślązaków i Kaszubów. Po raz pierwszy w historii polskich spisów odnotowano deklaracje przynależności regionalnych: kociewską ( 3,1 tys.), góralską ( 2,9 tys.), wielkopolską (1,5 tys.), mazurską (1,4 tys.), śląsko-cieszyńską ( 0,9 tys.), zagłębiowską ( 0,9 tys.), borowiacką ( 0,8 tys.), mazowiecką ( 0,3 tys.), kurpiowską ( 0,3 tys.). W zdecydowanej większości (ponad 90\%) były one - podobnie jak w przypadku Kaszubów - deklarowane na miejscu drugim, wraz z polską tożsamością narodową, czyli ich zaistnienie podczas spisu było bezpośrednią konsekwencją nowatorskiej metody sformułowania pytań etnicznych.

Spośród tzw. mniejszości tradycyjnych najliczniej byli reprezentowani, podobnie jak w poprzednim spisie, Niemcy, Ukraińcy i Białorusini, z tym że mniejszość białoruska i niemiecka odnotowała niewielki spadek liczebności w porównaniu z 2002 rokiem. W przypadku wszystkich pozostałych zbiorowości, posiadających oficjalny status mniejszości narodowych, etnicznych lub posługujących się językiem regionalnym, miał miejsce wzrost liczebności, jednak bardzo zróżnicowany w zależności od konfiguracji odpowiedzi na pytania etniczne. W kilku przypadkach (Kaszubi, Żydzi, Niemcy) był on równocześnie wyjątkowo silnie związany z polską tożsamością narodową (tab. 5). Na uwagę zasługuje także wykazana podczas spisu liczebność narodowości amerykańskiej, angielskiej, włoskiej czy francuskiej, lokująca te zbiorowości wśród kilkunastu najliczniejszych niepolskich narodowości zamieszkujących współczesną Polską. Trzeba jednak pamiętać, że ok. 90\% tych deklaracji to podwójna identyfikacja ze wskazaną na pierwszym miejscu narodowością polską (tab. 5).

\section{Wnioski}

Wszelkie statystyki narodowościowe, co słusznie podkreślali m.in. J. Tomaszewski (1985), P. Eberhardt (1996), H. Chałupczak i T. Browarek (1998), A. Gawryszewski (2005), L. Adamczuk i S. Łodziński (2006) oraz E. Gołata (2008, 2013), dotyczą kwestii bardzo delikatnych, subiektywnych i trudno mierzalnych, dlatego zawsze będą obarczone błędami, nie dostarczą ,idealnych” rezultatów, nie przedstawią rzeczywistej struktury narodowościowej, a ich wyniki będą budzić większe lub mniejsze emocje i kontrowersje oraz wymagać bardzo ostrożnej interpretacji. Ponadto ich wiarygodność jest niejednokrotnie wypadkową aktualnej polityki narodowościowej państwa w okresie spisowym 
oraz bieżących uwarunkowań społecznych i politycznych. Tezy te potwierdzają wszystkie spisy powszechne przeprowadzone w Polsce.

Spisy w roku 1921 oraz 1946 zostały przeprowadzone zbyt szybko po zakończeniu konfliktu zbrojnego - w bardzo dynamicznej sytuacji polityczno-społecznej, podczas powojennych migracji, nie na całym terytorium państwa, przed ostatecznym wytyczeniem granic, w warunkach bardzo silnych nastrojów nacjonalistycznych i wyraźnej niechęci polskiej większości do co najmniej części mniejszości narodowych. $Z$ punktu widzenia potrzeb administracji państwowej tak szybkie ich przeprowadzenie miało uzasadnione powody politycznej i demograficzne, ale nie sprawdziło się w przypadku rzetelnego ustalenia struktury narodowościowej, zaniżając liczebność mniejszości narodowych.

Spis w roku 1931 był przeprowadzony w realiach państwa wielonarodowego, bardzo silnie skonfliktowanego etnicznie. Na jego wyniki wpływ miała zarówno zmiana metody określania struktury narodowościowej, manipulacje i bezpośrednie fałszerstwa władz dążących do zaniżenia liczebności ludności niepolskiej, jak i dopiero kształtująca się tożsamość narodowa mieszkańców niektórych, zwłaszcza wschodnich, regionów ówczesnej Polski.

W 2002 roku, po kilkudziesięciu latach przerwy w badaniach dotyczących statystyki narodowościowej oraz 45 letnim okresie braku wolności słowa i demokracji, w realiach państwa praktycznie monoetnicznego, przyjęto jednoznaczny sposób zadania pytania o narodowość oraz bezpośrednią metodę pozyskiwania danych statystycznych. Jednak uwarunkowania społeczne, a zwłaszcza uzasadniona negatywnymi doświadczeniami historycznymi obawa części mniejszości przed deklarowaniem niepolskiej narodowości, przyczyniła się do zaniżenia jego wyników, co w połączeniu z wygórowanymi szacunkami dotyczącymi ówczesnej struktury narodowościowej Polski, spowodowało liczne zarzuty dotyczące rzetelności tego spisu.

Z kolei w 2011 roku spis został przeprowadzony metodą bardzo zróżnicowaną i całkowicie odmienną od wszystkich wcześniejszych. Zmiany wprowadzono głównie pod wpływem sugestii i żądań organizacji narodowościowych, w ramach tzw. poprawności politycznej w państwie, w którym mniejszości narodowe nie odgrywały istotnej roli demograficznej ani politycznej. Sformułowanie pytań dotyczących narodowości, a zwłaszcza obliczania, a raczej szacowania struktury narodowościowej - po raz pierwszy - istotnie zawyżyło, a nie zaniżyło jego wyniki oraz ograniczyło ich wiarygodność. Czynnikiem, który w największym stopniu wpłynął na deformację rezultatów była możliwość deklarowania podwójnej identyfikacji narodowej przy jednoczesnym „automatycznym” przypisaniu do mniejszości narodowych lub etnicznych osób, które zadeklarowały tożsamość „mniejszościową” na miejscu drugim, razem z dominującą identyfikacją polską.

Według autora deklaracje podwójnej tożsamości narodowej, stosowane łącznie z zasadą nadrzędności przynależności do mniejszości nad polską tożsamością narodową, silniej wypaczyły wyniki spisu w 2011 roku - zawyżając 
liczebność niepolskich narodowości - niż metoda przeprowadzenia spisu w 2002 roku oraz ówczesne uwarunkowania społeczne wpłynęły na zaniżenie liczebności mniejszości narodowych i etnicznych.

W zakresie pytań o narodowość żaden z omawianych spisów ludności nie był w pełni wiarygodny, a dla liczbowego określenia struktury narodowościowej Polski, zarówno w XX wieku, jak i w pierwszej dekadzie XXI wieku, większe znaczenie miały zastosowane podczas spisów zróżnicowane metody statystyczne oraz bieżąca polityka państwa wobec ludności niepolskiej niż subiektywne poczucie tożsamości narodowej poszczególnych obywateli.

Podsumowując omawianie struktury narodowościowej Polski określanej a raczej wykreowanej - na podstawie spisów powszechnych z lat 1921-2011, można w pełni zgodzić się z opinią Z. Rykla (2006), który stwierdził, że „statystyka narodowościowa to pozory liczebności poszczególnych grup etnicznych", a zwłaszcza z poglądem, według którego „liczebność poszczególnych grup etnicznych jest drugorzędną kwestią naukową i pierwszorzędną kwestią polityczną".

\section{LITERATURA}

Adamczuk L., Łodziński S. (red.), 2006, Mniejszości narodowe w Polsce w świetle Narodowego Spisu Powszechnego z 2002 roku, Warszawa.

Babiński G., 2004, Mniejszości narodowe i etniczne w Polsce w świetle spisu ludności z roku 2002, „Studia Socjologiczne”, 1(172), s. 139-152.

Barwiński M., 2004, Podlasie jako pogranicze narodowościowo-wyznaniowe, Łódź.

Barwiński M., 2006, Liczebność i rozmieszczenie mniejszości narodowych i etnicznych w Polsce w 2002 roku a wcześniejsze szacunki, [w:] Bieńkowska-Ptasznik M., Krzysztofek K., Sadowski A. (red.), Obywatelstwo i tożsamość w spoteczeństwach zróżnicowanych kulturowo i na pograniczach, t. 1, Białystok, s. 345-370.

Barwiński M., 2013, Geograficzno-polityczne uwarunkowania sytuacji Ukrainców, Lemków, Biatorusinów i Litwinów w Polsce po 1944 roku, Łódź.

Barwiński M., 2014, Struktura narodowościowa Polski w świetle wyników spisu powszechnego z 2011 roku, „Przegląd Geograficzny”, 86(2), s. 217-241.

Chałupczak H., 2006, Liczba mniejszości narodowych i etnicznych $w$ Polsce $w$ świetle powszechnego spisu ludności z 2002 roku oraz badań naukowych, [w:] Michalik E., Chałupczak H. (red.), Mniejszości narodowe $i$ etniczne w procesach transformacji oraz integracji, Lublin, s. 263-270.

Chałupczak H., Browarek T., 1998, Mniejszości narodowe w Polsce w latach 19181995, Wydawnictwo Uniwersytetu Marii Curie-Skłodowskiej, Lublin.

Eberhardt P., 1996, Między Rosją a Niemcami, Warszawa.

Eberhardt P., 2006, Przemiany struktury etnicznej ludności Polski w XX wieku, „Sprawy Narodowościowe. Seria Nowa”, 28, s. 53-74.

Eberhardt P., 2008, Struktura narodowościowa ludności Polski, „Rocznik Nauk Spolecznych”, 36(1), s. 145-170.

Eberhardt P., 2010, Migracje polityczne na ziemiach polskich (1939-1950), Poznań. 
Gawryszewski A., 2005, Ludność Polski w XX wieku, Monografie, 5, IGiPZ PAN, Warszawa.

Gołata E., 2008, Spisy ludności - możliwości i ograniczenia, [w:] Statystyka wczoraj, dziś i jutro, Biblioteka Wiadomości Statystycznych, 56, GUS, Warszawa, s. 72-84.

Gołata E., 2013, Spis ludności i prawda, „Studia Demograficzne”, 1(161), s. 23-55.

GUS, 2008, Wyniki Narodowego Spisu Powszechnego Ludności i Mieszkań 2002 w zakresie deklarowanej narodowości oraz języka używanego w domu (15.07.2008), http://www.stat.gov.pl/gus/.

GUS, 2013, Ludność. Stan i struktura demograficzno-społeczna (09.04.2013), http:// www.stat.gov.pl/.

Holzer Z., 1989, Demografia, Warszawa.

Hołuszko M., 1993, Mniejszości narodowe i etniczne w Polsce, „Społeczeństwo Otwarte”, 2, Warszawa.

Krysiński A., 1937, Ludność ukraińska (ruska) w Polsce w świetle spisu 1931, „Sprawy Narodowościowe", 11(6), s. 567-591.

Kurcz Z. (red.), 1997, Mniejszości narodowe w Polsce, Wrocław.

Łodziński S., 2005, Równość i różnica. Mniejszości narodowe w porządku demokratycznym w Polsce po 1989 roku, Warszawa.

Łodziński S., 2006, Trauma $i$ władza liczb. Wybrane problemy spolecznego odbioru pytania o „narodowość” w Narodowym Spisie Powszechnym z 2002 roku, [w:] Adamczuk L., Łodziński S. (red.), Mniejszości narodowe $w$ Polsce $w$ świetle Narodowego Spisu Powszechnego z 2002 roku, Warszawa, s. 171-208.

Makowski B., 1986, Litwini w Polsce 1920-1939, Warszawa.

Nijakowski L., Łodziński S. (red.), 2003, Mniejszości narodowe i etniczne w Polsce. Informator 2003, Komisja Mniejszości Narodowych i Etnicznych, Warszawa.

Olejnik L., 2003, Polityka narodowościowa Polski w latach 1944-1960, Łódź.

Rykiel Z., 2006, Podstawy geografii politycznej, Warszawa.

Sakson A., 1991, Mniejszość niemiecka na tle innych mniejszości narodowych we wspótczesnej Polsce, „Przegląd Zachodni”, 47, s. 1-23.

Sobczyński M., 2000, Struktura narodowościowo-wyznaniowa Polski, „Acta Universitatis Lodziensis”, Folia Geographica Socio-Oeconomica, 3, Łódź, s. 157-174.

Sobczyński M., 2012, Interakcja „badacz - podmiot badania” w studiach nad mniejszościami narodowymi w Polsce, Studia z Geografii Politycznej i Historycznej, t. 1, Łódź, s. 95-112.

Statystyka Polski, 1938, Drugi Powszechny Spis Ludności z dnia 9 XII 1931 roku, Seria C, Warszawa.

Statystyka Polski, 1947, Seria D - Powszechny sumaryczny spis ludności z dnia 14 lutego 1946 roku, z. 1, Warszawa.

Szczygielski K., 2006, Geografia mniejszości narodowych i etnicznych w Polsce. Ujęcie ilościowe, Opole.

Tomaszewski J., 1985, Ojczyzna nie tylko Polaków, Warszawa.

Wasilewski L., 1927, Istotna liczba Ukraińców w Polsce, „Sprawy Narodowościowe”, 5-6, s. 227-236.

Zaborski B., 1937, Liczba i rozmieszczenie mieszkańców Polski wedtug języków i wyznań (uwagi ogólne w świetle spisu 1931 r.), „Sprawy Narodowościowe”, 11(1-2), s. 75-86. 


\title{
CENSUSES IN POLAND IN THE YEARS 1921-2011 - DETERMINATION OR CREATING OF ETHNIC STRUCTURE?
}

\begin{abstract}
This article attempts to answer question on how much the methods of conducting censuses, the formulation of the so-called "ethnic question" and current political and social conditions can shape their results. The census carried out in Poland over the last 90 years were discussed, paying particular attention to factors that could cause distortion of their results.
\end{abstract}

Censuses in 1921 and 1946 were carried out immediately after the end of armed conflict - in a very dynamic socio-political situation during the post-war migration, not on the entire territory of the country, before the final demarcation of borders, in conditions of very strong nationalist atmosphere and marked reluctance of Polish majority to at least part of national minorities. From the point of view of the state administration the rapid pace of their conduction had justified reasons of political and demographic character, however it did not worked in the case of a reliable determination of the national structure, due to underestimating of the size of national minorities.

The census in 1931 was carried out in the realities of a multinational state, strongly conflicted ethnically. On its results influenced both, the change in the method of determining the national structure, direct manipulation and forgery of authorities seeking to underestimation of the number of non-Polish population, as well as the emerging national identity of some residents, especially of eastern regions of the Poland.

In 2002, after several years of recess in the studies on ethnic statistics, in the realities of practically mono-ethnic state, the clearly method of question of nationality and direct method of obtaining statistical data were adopted. However the social conditions, and particularly the negative experience of part of the minority against declaring non-Polish nationality, has contributed to an underestimation of its results, what combined with excessive estimates of the then Polish ethnic structure, caused numerous complaints concerning the accuracy of the census.

In turn, in 2011, the census was carried out by a very diverse and completely different from all previous ones method. The introduced changes were mainly influenced by the suggestions and requests of national organizations, under what is known as "political correctness" in the country in which minorities did not play a significant role in demographic or political aspect. The formulation of a questions about nationality, and especially the computation or rather estimation of the ethnic structure - for the first time - clearly overrated, not underrated its results and reduced their credibility.

In terms of questions about nationality, none of these censuses were fully reliable, and for quantifying the Polish ethnic structure, the greater importance had rather different statistical methods applied during censuses, and the current state policy against non-Polish population, rather than the subjective feeling of national identity of individual citizens.

Key words: the national structure of Poland, census, national minorities.

Dr hab. Marek Barwiński, prof. UŁ Katedra Geografii Politycznej i Studiów Regionalnych Wydział Nauk Geograficznych Uniwersytet Łódzki 